\title{
Pembinaan Masyarakat dalam Pengolahan Sampah Peternakan untuk Mengembangkan Pertanian Organik
}

\author{
Ahmad Raksun $^{1 *}$, Wayan Merta ${ }^{1}$, I Gede Mertha ${ }^{1}$, Moh. Liwa Ilhamdi ${ }^{1}$

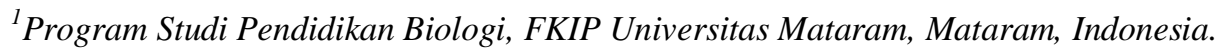

DOI: https://doi.org/10.29303/jpmsi.v2i2.76

Citation: Raksun, A., Merta, W., Mertha, I., G., Ilhamdi, M., L. 2020. Pembinaan Masyarakat dalam Pengolahan Sampah Peternakan untuk Mengembangkan Pertanian Organik. Jurnal Pengabdian Masyarakat Sains Indonesia (JPMSI). 2(2): 126-130.

Article history

Received: October $20^{\text {th }} 2020$

Revised: October $28^{\text {th }} 2020$

Accepted: November $14^{\text {th }} 2020$

*Corresponding Author: Ahmad Raksun, FKIP Universitas

Mataram, Mataram, Indonesia. Email:

ahmadunram@unram.ac.id

\begin{abstract}
Abstrak: Kegiatan pengabdian kepada masyarakat ini telah dilaksanakan di Desa Terong Tawah Kecamatan Labuapi Kabupaten Lombok Barat. Masalah utama yang dihadapi mitra adalah: (1) mitra belum menemukan alternatif pemecahan masalah sampah yang dihasilkan dari kegiatan peternakan, (2) mitra tidak memiliki pengetahuan tentang teknik pemupukan tanaman dalam budidaya tanaman organik. Solusi untuk mengatasi masalah petama adalah dengan mengolah sampah peternakan menjadi pupuk organik bokashi. Bokashi adalah kompos yang dihasilkan melaui fermentasi dengan pemberian Effective Microorganism 4 (EM4). Untuk mengatasi masalah kedua maka tim melakukan pendampingan kepada mitra dalam pemupukan tanaman khususnya dalam budidaya tanaman organik. Tanaman organik yang dibudidayakan mitra adalah cabai rawit, jagung manis dan kacang panjang. Pelaksanaan kegiatan dilakukan dengan metode ceramah, tanya jawab dan pendampingan. Setelah berakhirnya kegiatan ini, mitra memiliki pengetahuan dan keterampilan tentang teknik pengolahan sampah organik menjadi bokashi. Mitra memiliki pengetahuan dan keterampilan tentang teknik pemupukan tanaman menggunakan bokashi dalam budidaya tanaman organik. Mitra kegiatan ini memiliki respons yang baik terhadap pelaksanaan kegiatan
\end{abstract}

Kata Kunci: Pengolahan sampah peternakan, mengembangkan pertanian organic.

sapi, kuda atau kambing. Ternak sapi, kuda dan kambing masyarakat tani Desa Terong Tawah dipelihara dengan cara dikandangkan. Posisi kandang ternak biasanya berdampingan dengan rumah pemilik ternak. Khusus di Dusun Terong Tawah Presak, ternak sapi dipelihara dalam kandang kolektif. Peternak kuda memelihara kuda untuk digunakan sebagai penarik alat transportasi cidomo, sedangkan yang memelihara sapi dan kambing bertujuan untuk dikembangbiakkan.

Setelah jumlah sapi dan kambing menjadi banyak maka sebagian akan dijual untuk memenuhi keutuhan hidup sehari-hari. Kegiatan peternakan sapi, kuda dan kambing yang dilakukan oleh masyarakat tani Desa Terong Tawah menghasilkan sampah berupa kotoran ternak dan sisa makanan ternak. Sisa makanan ternak biasanya dimusnahkan dengan cara dibakar sedangkan kotoran ternak biasanya tani memiliki usaha sampingan yaitu beternak 
Raksun et al, Jurnal Pengabdian Masyarakat Sains Indonesia 2020, 2 (2): 125-130. DOI : https://doi.org/10.29303/jpmsi.v2i2.76

dibuang ke kali sehingga berdampak negatif terhadap kebersihan air kali.

Petani Desa Terong Tawah memiliki penghasilan yang rendah. Rendahnya penghasilan masyarakat tani terutama disebabkan oleh rendahnya hasil usaha pertanian yang mereka lakukan sebagai dampak dari minimnya pengetahuan masyarakat khususn tentang teknik pemupukan tanaman. Selama ini masyarakat melakukan pemupukan tanaman menggunakan pupuk kimia sintetik seperti pupuk urea dan NPK. Penggunaan pupuk kimia sintetik secara terus menerus dalam waktu yang lama tampa adanya penggunaan pupuk organik menyebabkan terjadinya degradasi fungsi lahan pertanian dan kebutuhan pupuk kimia makin lama makin tinggi. Zulkarnaen (2014) menjelaskan bahwa aplikasi input kimiawi yang berupa pupuk dan festisida sintetik dengan dosis tinggi tidak hanya berpengaruh menurunkan tingkat kesuburan tanah, tetapi juga mengakibatkan pada merosotnya keanekaragaman hayati, meningkatnya serangan hama dan penyakit, timbulnya hama yang resisten dan berkembangnya organisme parasit. Selain itu dampak negatif dari penggunaan infut kimiawi tidak hanya terbatas pada daerah pemakaian tetapi dapat menjadi makin luas melalui komponen rantai makanan seperti air minum, sayuran, buah- buahan dan produk-produk lain yang terkontaminasi.

Sampai saat sekarang ini peternak sapi, kuda dan kambing Desa Terong tawah belum menemukan alternatif pemecahan masalah sampah peternakan kuda, kambing dan sapi yang ada di sekitar tempat tinggal mereka. Pengolahan sampah peternakan menjadi pupuk organik bokashi merupakan alternatif pemecahan masalah yang dapat diterapkan untuk mengatasi permasalahan yang dihadapi peternak sapi, kuda dan kambing Desa Terong Tawah. Pupuk organik yang dihasilkan dapat dijadikan pupuk untuk mengurangi penggunaan pupuk kimia dan meningkatkan hasil panen tanaman. Hasil penelitian Lawenga dkk (2015) menunjukkan bahwa pemberian pupuk organik dapat memperbaiki sifat fisika tanah terutama pada bobot isi tanah, porositas dan permeabelitas. Demikian juga Nuro dkk (2016) menyimpulkan bahwa aplikasi pupuk organik berpengaruh terhadap sifat kimia tanah dan produksi kangkung darat . Lebih lanjut hasil penelitian Raksun dkk (2019) pada tanaman melon menunjukkan bahwa
e-ISSN : $2715-2537$

p-ISSN : 2715-2545

aplikasi pupuk organik dapat meningkatkan pertumbuhan melon. Demikian juga peneltian pada tanaman terong hijau yang dilakukan Raksun dkk (2019) menunjukkan bahwa pemberian pupuk organik dapat meningkatkan pertumbuhan tanaman terong hijau.

Berdasarkan uraian di atas maka kami tim pelaksana pengabdian pada masyarakat Universitas Mataram, berupaya menjadikan masyarakat tani Desa Trong Tawah yang memiliki ternak sapi, kuda atau kambing sebagai mitra pelaksanaan pengabdian pada masyarakat. Ada dua permasalahan utama yang dihadapi oleh mitra, yaitu: (1) mitra belum menemukan alternatif pemecahan masalah sampah yang dihasilkan dari kegiatan peternakan sapi, kuda dan kambing (2) mitra tidak memiliki pengetahuan tentang teknik pemupukan tanaman dalam budidaya tanaman organik.

\section{Metode}

Sampah yang dihasilkan dari kegiatan peternakan sapi, kuda dan kambing di Desa Terong Tawah diolah menjadi produk yang bermanfaat (pupuk organik bokashi). Pembuatan bokashi dilakukan dengan teknologi biofermentasi EM4. Metode yang digunakan adalah ceramah, diskusi, pelatihan dan pendampingan. Adapun tahapan kerja pengolahan sampah peternakan sapi, kuda dan kambing menjadi bokashi dan pemanfatannya untuk pengembangan pertanian organik adalah sebagai berikut: (1) persiapan, pada tahap persipan dilakukan diskusi internal tim pelaksana pengabdian serta mengumpulkan alat dan bahan yang diperlukan, (2) sosialisasi, kegiatan sosialisasi dilakukan kepada mitra menggunakan metode cermah dan tanya jawab. Pada saat sosialisasi, tim pelaksana menyampaikaan maksud dan tujuan pelaksanaan kegiatan kepada masyarakat, (3) pengolahan sampah peternakan menjadi pupuk organik bokashi, kegiatan ini dilakukan dengan penerapan teknologi biofermentasi EM4. Kotoran ternak dicampur dengan sekam dan dedak halus. Selanjutnya campuran tersebut dibasahi dengan larutan gula EM4. Bahan baku bokashi difermentasi selama 30 hari, selanjutnya bokashi dibawa kelahan pertanian,, (4) pengembangan pertanian organik, tanaman organik adalah tanaman yang diberi infut unsur hara menggunakan pupuk organik tanpa adanya 
Raksun et al, Jurnal Pengabdian Masyarakat Sains Indonesia 2020, 2 (2): 125-130. DOI : https://doi.org/10.29303/jpmsi.v2i2.76

pemberian pupuk kimia sintetik. Berdasarkan hasil diskusi tim pelaksana pengabdian dengan mitra, tanaman organik yang dibudidayakan adalah tanaman kacang panjang, cabai rawit dan jagung manis. Lahan pertanian (sawah) yang sudah diolah, dibuat bedengan dengan lebar $90 \mathrm{~cm}$ dan panjang 10 meter. Pada bedengan lahan diaplikasikan pupuk organik bokashi. Selanjutnya pada bedengan lahan ditanami jagung manis, kacang panjang dan cabai rawit. Penanaman kacaang panjang, jagung manis dan cabai rawit dilakukan setelah 18 hari pemberian pupuk organik bokashi.

\section{Hasil dan Pembahasan}

Dalam kegiatan ini ada dua permasalahan utama yang dihadapi oleh mitra, yaitu: (1) mitra belum menemukan alternatif pemecahan masalah sampah yang dihasilkan dari kegiatan peternakan sapi, kuda dan kambing (2) mitra tidak memiliki pengetahuan tentang teknik pemupukan tanaman dalam budidaya tanaman organik. Solusi yang dilakukan dalam upaya mengatasi permasalahan pertama adalah dengan mengolah sampah peternakan menjadi pupuk organik bokashi. Bokashi adalah kompos yang dihasilkan melaui fermentasi dengan pemberian Effective Microorganism 4 (EM4), yang merupakan salah satu aktivator untuk mempercepat proses pembuatan kompos (Indriani, 2001). Selanjutnya menurut Teruo (1999), bokashi adalah pupuk kompos yang dihasilkan dari proses fermentasi atau peragian bahan organik dengan teknologi EM4 (Effective Microorganisms 4). Keunggulan penggunaan teknologi EM4 adalah pupuk organik dapat dihasilkan dalam waktu yang relatif singkat dibandingkan dengan cara konvensional. EM4 sendiri mengandung Azotobacter sp., Lactobacillus sp., bakteri fotosintetik dan jamur pengurai selulosa. Pengolahan sampah peternakan menjadi pupuk organik, menjadikan lingkungan sekitar Desa Terong Tawah menjadi bersih dari sampah peternakan. Selain itu bokashi yang dihasilkan dapat digunakan untuk memupuk tanaman dalam pengembangan tanaman organik. Untuk
e-ISSN : 2715-2537

p-ISSN : 2715-2545

mengatasi masalah kedua maka tim memberikan solusi dengan melakukan pendampingan kepada masyarakat dalam pemupukan tanaman khususnya dalam budidaya tanaman organik. Tanaman organik yang dibudidayakan mitra adalah cabai rawit, jagung manis dan kacang panjang.

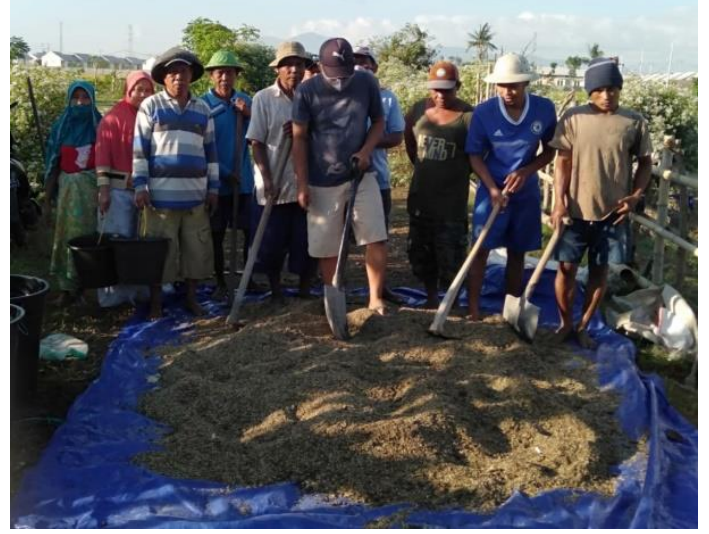

Gambar 1. Pembuatan Pupuk Organik Bokashi oleh

Mitra

Upaya pemecahan masalah mitra yang dilakuan tim pelaksana pengabdian pada masyarakat mengacu pada hasil penelitian yang sudah dilkukan oleh tim pelaksanan dan penelitipeneliti yang lain. Hasil penelitian yang sudah dilakukan oleh Raksun dan Santoso (2010) menyimpulkan bahwa pemberian bokashi pada lahan pertanian dapat meningkatkan produksi tomat. Demikian juga penelitian pada tanaman cabai rawit disimpulkan bahwa pemberian bokashi berpengaruh nyata terhadap produksi cabai rawit (Raksun dan Mertha, 2017). Sejumlah peneliti lain menyimpulkan bahwa pemberian bokashi berpengaruh sangat nyata terhadap tinggi dan berat segar tanaman caisin (Tomia,2012).

Pemberian berbagai jenis bokashi memberikan pengaruh yang sangat nyata terhadap pertumbuhan dan hasil jagung manis (Mulyanti dkk, 2015). Pemupukan bokashi dengan dosis 20 ton per hektar memberikan bobot gabah kering per hektar tertinggi (4,70 ton), jumlah anakan produktif tertinggi $(25,00)$ dicapai varietas cianjur (Mulyana dkk, 2011). Pemberian pupuk 
Raksun et al, Jurnal Pengabdian Masyarakat Sains Indonesia 2020, 2 (2): 125-130. DOI : https://doi.org/10.29303/jpmsi.v2i2.76

bokashi Eceng Gondok menunjukkan respon sangat nyata pada total produksi kedelai per plot (Hasibuan dkk, 2017). Penambahan bokashi dalam dosis 250 g pada media tanah NPK dapat mendukung pertumbuhan cabe var. Inko 99 lebih optimal dengan tinggi tanaman $71,15 \mathrm{~cm}$ dan jumlah cabang produktif 40,75 buah (Gustia, 2009). Aplikasi bokashi berpengaruh pada pertumbuhan vegetatif dan produksi rumput gajah. Bokashi 30 ton per hektar memberikan pertumbuhan vegetatif dan produksi rumput gajah tertinggi (Kusuma, 2013). Media terbaik untuk pertumbuhan semai eboni adalah pupuk organik EM bokashi karena media ini dapat meningkatkan solubilitas dan viabilitas hara dalam tanah dan memberikan pertumbuhan semai eboni yang optimal (Sumiasri dan Setyowati, 2006).

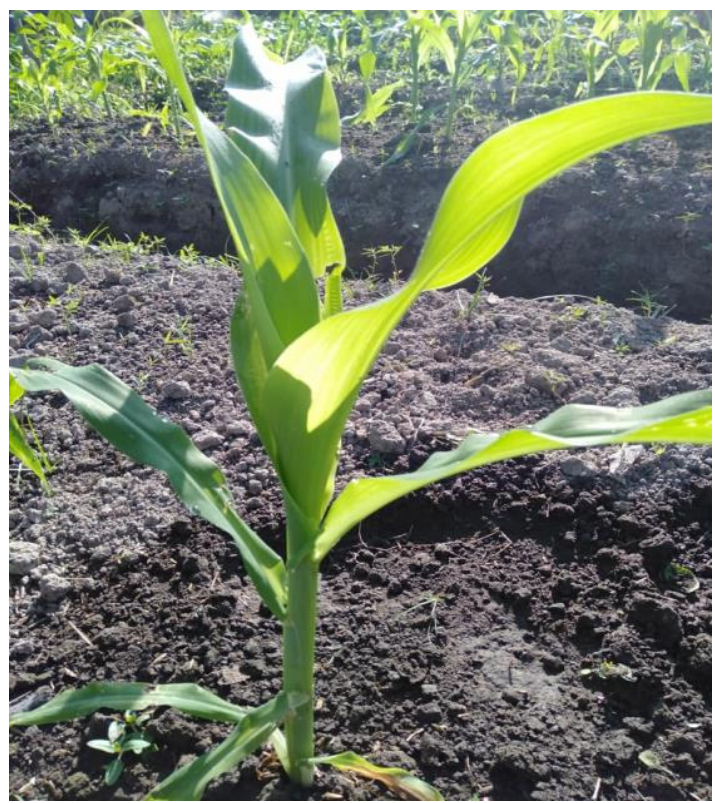

Gambar 2. Tanaman Jagung Manis yang dipupuk dengan bokashi

Pada pelaksanaan kegiatan pengabdian pada masyarakat ini nampak bahwa masyarakat yang menjadi mitra kegiatan telah mengikuti kegiatan dengan baik mulai dari sosialisasi kegiatan sampai pada saat pelaksanan pembuatan bokashi dan penggunaan bokashi pada lahan pertanian. Hal ini dapat dilihat dari banyaknya pertanyaan yang diajukan peserta yang terkait dengan materi yang disampaikan tim pelaksana pada saat diskusi. Selain itu pada saat praktek pembuatan bokashi semua peserta ikut bekerja secara aktif sehingga kegiatan paraktek pembuatan bokashi dapat berjalan sesuai dengan waktu yang direncanakan.
e-ISSN : 2715-2537

p-ISSN : 2715-2545

Pelaksanaan kegiatan pengabdian seperti ini sangat penting artinya bagi masyarakat mitra karena melalui kegiatan ini mereka dapat memahami berbagai dampak yang mungkin timbul sebagai akibat banyaknya sampah kotoran ternak yang dihasilkan dari kegiatan peternakan sapi, kuda dan kambing. Selanjutnya mereka diharapkan dapat melakukan pencegahan terhadap timbulnya dampak tersebut dengan tidak membuang sampah disembarang tempat dan memanfaatkan sampah organik kotoran sapi, kuda dan kambing sebagai bahan baku pembuatan bokashi untuk meningkatkan pertumbuhan tanaman yang dibudidayakan di lahan persawahan mapun di pekarangan rumah.

Bokashi yang dibuat mitra difermentasi selama 30 hari. Setelah selesai pembuatan bokashi dengan bahan baku kotoran ternak, kegiatan dilanjutkan dengan penggunaan bokashi sebagai pupuk pada lahan pertanian dalam pengembangan tanaman organik. Pemupukan tanaman menggunakan bokashi dilakukan pada tanaman jagung manis, cabai rawit dan kacang panjang dengan langkah kerja sebagai berikut: (1) pembuatan bokashi oleh mitra, (2) pembibitan tanaman cabai rawit, (3) pembuataan bedengan pada lahan yang akan ditanami tanaman jagung manis, cabai rawit, dan kacang panjang, (4) pemberian bokashi pada bedengan dengan dosis $1,5 \mathrm{~kg}$ bokashi per $1 \mathrm{~m}^{2}$ lahan pertanian, (5) mencampur tanah pada bedengan dongan bokashi sampai tercampur secara merata, (7) penanaman bibit cabai rawit yang sudah disiapkan, (8) penanaman benih kacang panjang dan jagung manis, (9) melakukan perawatan tanaman jagung manis, cabai rawit dan kacang panjang.

Setelah disampaikan materi pengabdian, mitra dapat memahami dampak negatif yang ditimbulkan oleh kegiatan pembuangan sampah peternakan disembarang tempat. Selain itu mitra sampai saat ini belum memiliki alternatif pemecahan masalah sampah petrnakan yang ada disekitar tempat tinggal mereka. Selama ini mereka menumpuk kotoran kernak disekitar kandang ternak dan membuangnya ke kali pada saat musim hujan. Kondisi tersebut merupakan faktor pendorong bagi peserta dalam mengikuti kegiatan ini. Melalui kegiatan ini, mereka memahami dan menyadari bahwa jika sampah yang mereka hasilkan dibuang disembarang tempat dapat menimbulkan berbagai dampak negatif bagi lingkungan. Dengan demikian mereka memiliki keinginan yang kuat untuk 
Raksun et al, Jurnal Pengabdian Masyarakat Sains Indonesia 2020, 2 (2): 125-130. DOI : https://doi.org/10.29303/jpmsi.v2i2.76

menjadi peserta kegiatan ini dan memanfaatkan sampah khususnya kotoran sapi, kuda dan kambing yang ada disekitar tempat tinggal mereka sebagai bahan baku pembuatan pupuk organik bokashi serta memanfaatkan bokashi untuk meningkatkan pertumbuhan tanaman pada lahan pertanian yang mereka miliki. Selain itu pengolahan sampah kotoran sapi, kuda dan kambing menjadi bokashi dapat meningkatkan kebersihan lingkungan.

Faktor penghambat pelaksanaan kegiatan pengabdian pada masyarakat ini adalah sulitnya menentukan jadwal kegiatan karena adanya berbagai tugas dikampus sperti melaksanakan perkuliahan, membimbing skripsi mahasiswa, tugas bimbingan akademik dan lain-lain. Selain itu masyarakat mitra memiliki kesibukan rutin seperti mengolah lahan pertanian, mencari makanan ternak dan kegiatan-kegiatan lainnya Kondisi tersebut menyebabkan tim pelaksana merasa kesulitan dalam menentukan waktu pelaksanaan kegiatan. Tim pengabdian masyarakat harus mengatasi hambatan tersebut dengan cermat agar waktu pelaksanaan kegiatan pengabdian tidak berbenturan dengan waktu perkuliahan di Universitas Mataram. Faktor penghambat lainnya adalah kurangnya air yang tersedia untuk mengairi lahan pertanian pada saat penanaman tanaman jagung manis, cabai rawit dan kacang panjang karena kegiatan pengabdian ini dilakukan pada musim kemarau. Hambatan ini dapat diatasi dengan menyewa mesin pompa air untuk memompa air yang ada pada sumur disekitar lahan pertanian yang dijadikan sebagai lahan penenaman tanaman uji coba penggunaan bokashi (Jagung manis, cabai rawit dan kacang panjang).

\section{Kesimpulan}

Berdasarkan hasil pelaksanaan kegiatan yang meliputi kegiatan penyampaian materi, praktek pembuatan bokashi, penggunaan bokashi dalam pengembangan tanaman organik sampai dengan akhir pelaksanaan kegiatan maka dapat disimpulkan bahwa: (1) setelah berakhirnya kegiatan ini, masyarakat Desa Terong Tawah Kecamatan Labuapi Kabupaten Lombok Barat yang menjadi mitra kegiatan ini memiliki pengetahuan dan keterampilan tentang teknik pengolahan sampah organik khususnya kotoran sapi, kotoran kuda dan kotoran kambing menjadi bokashi, (2) mitra kegiatan pengabdian pada masyarakat ini memiliki pengetahuan dan keterampilan tentang teknik pemupukan tanaman menggunakan bokashi, (3)
e-ISSN : 2715-2537

p-ISSN : 2715-2545

masyarakat Desa Terong Tawah yang menjadi mitra kegiatan ini memiliki respons yang baik terhadap pelaksanaan kegiatan dan berkomitmen untuk moncoba memanfaatkan limbah yang dihasilkan dari usaha peternakan sapi, kuda dan kambing yang ada disekitar tempat tinggal mereka sebagai bahan baku pembuatan bokashi. Selanjutnya menggunakan bokashi untuk meningkatkan hasil panen tanaman yang ada di pekarangan maupun pada lahan persawahan yang mereka miliki.

\section{Saran}

Kegiatan pengabdian semacam ini sangat bagus untuk dilakukan. Semoga kedepannya kegiatan pengabdian ini bisa terus dilakukan dengan tema-tema kegiatan yang lebih inovatif sehingga bermanfaat untuk masyarakat luas.

\section{Ucapan Terima Kasih}

Termakasih yang sebesar-besarnya kami sampaikan kepada Rektor Universitas Mataram yang telah memfasilitasi penyediaan dana pelaksanaan pengabdian pada masyarakat. Terimakasih juga kami sampaikan kepada Ketua LPPM Universtas Mataram dan semua pihak yang telah membantu pelaksanaan pengabdian pada masyarakat ini.

\section{Daftar Pustaka}

Gustia, H. 2009. Pengaruh pemberian Bokashi Terhadap pertumbuhan dan produksi tanaman cabe var. inko-99. Akta Agrosia Vol. 12(2): 113 - 123.

Hasibuan, S., Mawarni, R., Hendriandri, R. 2017. Respon Pemberian Pupuk Bokashi Ampas Tebu dan Pupuk Bokashi Eceng Gondok terhadap Pertumbuhan dan Produksi Tanaman Kedelai. Bernas Vol. 13 (2): 59 $-64$

Indriani, Y. H. 2001. Membuat Kompos Secara Kilat. Penebar Swadaya. Jakarta. Kusuma, M.E. 2013. Pengaruh Pemberian Bokashi terhadap Pertumbuhan dan Produksi Rumput Gajah (Penisetum purpureum). Ilmu Hewani Tropika. Vol 2 (2): 40 -45.

Kusuma, M.E. 2013. Pengaruh Pemberian Bokashi terhadap Pertumbuhan Vegetatif dan Produksi Rumput Gajah. Ilmu Hewani Tropika. Vol. 2(2): $40-45$ 
Raksun et al, Jurnal Pengabdian Masyarakat Sains Indonesia 2020, 2 (2): 125-130. DOI : https://doi.org/10.29303/jpmsi.v2i2.76

Lawenga, F.F., U. Hasanah dan D. Widjajanto. 2015. Pengaruh Pemberian Pupuk Organik terhadap Sifat Fisika Tanah dan Hasil Tanaman Tomat (Lycopersicum esculentum Mill.) di Desa Bolupuontu Kecamatan Sigi Biromaru Kabupaten Sigi. Agrotekbis Vol. 3 (5): 564 - 570.

Mulyana, D., Sahidin dan A. Iqbal. 2011. Pengaruh Dosis Bokashi terhadap Pertumbuhan dan Hasil Tiga Varietas Padi. Agrin. Vol. 15(1): $18-26$

Mulyanti, S.S., U. Made dan I. Wahyudi. 2015. Pengaruh Pemberian Berbagai Jenis Bokashi terhadap Pertumbuhan dan Hasil Jagung Manis (Zea mays Saccarata). Agrotekbis. Vol. 3(5) : $592-601$

Nuro, F., D, Priyadi dan E.S. Mulyaningsih. 2016. Efek Pupuk Organik terhadap Sifat Kimia Tanah dan Produksi Kangkung Darat (Ipomoea reptans Poir). Proseding Seminar Nasional Hasil-Hasil Penelitian IPB. ISBN: 978-602-8853-29-3. Halaman $29-39$

Raksun, A. dan D. Santoso, 2010. Pemanfaatan Bokashi Untuk Meningkatkan Pertumbuhan dan Produksi Tomat. Biologi Tropis. Vol 11(1): 44-50

Raksun, A. dan I.G. Mertha. 2017. Pengaruh Bokashi terhadap Produksi Cabawi Rawit. Biologi Tropis Vol. 17 (2): 45 - 5

Raksun A., L. Japa dan I.G. Mertha. 2019. Aplikasi Pupuk Organik dan NPK untuk Pertumbuhan Vegetatif dan Produksi Buah Terong Hijau. Jurnal Penelitian pendidikan IPA. Vol. 5 (2): 159 - 154

Raksun A., L. Japa dan I.G. Mertha. 2019. Aplikasi Pupuk Organik dan NPK untuk Meningkatkan Pertumbuhan Vegetatif Melon (Cucumis melo L.). Biologi Tropis. Vol. 19 (1) : $19-24$

Sumiarsi, N dan Setyowati, 2006. Pengaruh beberapa Media TerhadapPertumbuhan Bibit Eboni (Diospyros celebica Bakh). Melalui Perbanyakan biji. Biodipersitas. Vol 7(3): 260-263

Tomia, A. 2012 Pemanfaatan Bokashi Kotoran Ternak Ayam terhadap Produksi Tanaman Caisin. Agribisnis dan perikanan (Agrikan). Vol 5 (2) p. $20-24$
e-ISSN : $2715-2537$ p-ISSN : 2715-2545

Zulkarnain. H. 2014. Dasar-Dasar Hortikultura. Bumi Aksara. Jakarta. 